\title{
The Regional Crime Novel as Mediator of Heimat
}

\begin{abstract}
In recent years, a topographical shift has become apparent in crime fiction. This focus on the locus criminalis may be explained both by globalization and an ongoing search for cultural identity, and it influences the German literature market through the still-booming regional crime novel. The aims of this article are to determine the genre's main characteristics, to relate them to so-called Heimatliteratur, and to present both the mechanisms that convey an image of Heimat and the genre's relationship to the omnipresent question of identity. It will be shown that the regional crime novel tries to convey a very detailed image of a particular region by using textual and paratextual elements. As well as through depiction of the setting, regional identity is further strengthened by the use of dialect as well as references to traditional food. Thus, it is not surprising to find that these depictions are heavily associated with stereotypes and clichés. In a nutshell, the regional crime novel can be seen as one of many media products to deal with new developments presupposed by globalization and the urge to preserve one's origins by conveying a specific image of Heimat to readers.
\end{abstract}

Keywords: genre theory, Heimat, Heimatliteratur, regional crime novel, regional identity construction

\section{Introduction}

In the last three decades, an ongoing boom in the regional crime novel has had a considerable influence on the German literature market. The aims of this article are as follows: firstly, to lay out general developments in crime fiction; secondly, to relate these findings to the first successful examples of the regional crime novel, Jacques Berndorf's Eifelkrimis; thirdly, to determine the genre's main characteristics and relate them to so-called Heimatliteratur; fourthly, to present the mechanisms of regional crime novels that convey an image of Heimat; and finally, to start the process of providing an answer to the question of why there is an urge for Heimat in contemporary society. 


\section{General developments in crime fiction}

As Eva Erdmann points out, in recent years there has been a shift of focus in crime fiction. The most visible aspect of this consists of the detective novel series that concentrate primarily on setting (Erdmann 2009, 11-12). Thus, Erdmann concludes that "crime fictions' primary distinguishing characteristic has become the locus criminalis" $(2009,12)$.

Explaining this shift is quite easy. Murder has become an everyday event, a banality. Audiences have become used to crime fiction and stereotypical investigations. The expectations of audiences can now be represented as a matrix of motive, murderer, victim, crime scene, and so on. Any combination of each of these possibilities can be used to construct yet another stereotypical crime novel. Consequently, murder and investigation are no longer the main point of interest for the reader. Instead, that has now become the location and the figures of the novel (Erdmann 2009, 17-19). As another motivation for this attention-shift towards setting, one may name globalization. Not only goods but also crime fiction have become international. Crime novels now unfold in many different locations worldwide. Their task lies in combining an international background with location studies, which inevitably establishes a relationship with travel writing (Erdmann 2009, 13-15).

Why would this be done? Not only the crime novel itself but also its readership has become international and tends to be more familiar with an unknown geography. For authors such as Donna Leon, Henning Mankell, or Elizabeth George, portraying the setting has become a narrative strategy. This strategy has a strong influence on the ongoing success of their novels (Erdmann 2009, 16-17; Erdmann 2011, 274-275). However, this topographical shift is not merely the result of interest in getting to know a new location. As Erdmann points out, during the second half of the twentieth century the interest in crime has been replaced by a search for cultural identity. This tendency can be observed especially in nations where the topics of migration and multiculturalism are omnipresent, like in the United States (Erdmann 2009, 19).

There is also an ongoing search for cultural identity in Germany, where the regional crime novel is booming. Among the first examples are Jacques Berndorf's novels, situated in the Eifel mountain range. Meanwhile, more or less every German region - from Swabia and Bavaria up to Sylt or the Baltic coast - has its own crime novel series (Frackman 2014, 26). Thus, the focus is now placed on the region rather than the nation. According to Regula Venske (2014, 51), this fact might create the impression that Germany is not a unified state but rather the non-unified country it had been before 1871 . This poses the question of how the setting is depicted in the novels in question. 
In the following section, we will see if the findings of Erdmann concerning international crime fiction also apply to the German regional crime novel. To examine whether the locus criminalis and the characters form the focus of the novel, and whether there exists an urge to establish a cultural identity, we will look at Jacques Berndorf's Eifelkrimis.

\section{The Eifelkrimis of Jacques Berndorf}

Melanie Wigbers has published her work about the development of the locus criminalis in German literature from the nineteenth century to the present day. The findings of her work - which is also concerned with the novels of Jacques Berndorf - also support the thesis of the newly prominent importance of setting for the regional crime novel.

In Jacques Berndorf's Eifelkrimis, the plot always begins in Brück, the home town of the protagonist. The investigations take place across the whole region and beyond. ${ }^{1}$ The crimes are both specifically connected to the Eifel and of international significance (Wigbers 2006, 205, 211). For instance, in Der letzte Agent [The Last Agent] (Berndorf 2005), the members of a former spy ring from the German Democratic Republic that now operates internationally are either killed, kill themselves, or hide in the Eifel, because there is no other place in Germany where so little happens. Unfortunately, the protagonist, Siggi Baumeister, finds the first corpse when he is walking alone through the woods.

Baumeister is not a native of the Eifel, though he has been living there for a long time. He has a strong emotional bond to the whole region and not just his home town. Actually a journalist, he investigates on his own and becomes a blend of classical and hard-boiled detective. He receives some support from the police, but relies mainly on friends and acquaintances (Wigbers 2006, 209).

In the course of the investigation, not only the landscape but also the inhabitants are portrayed. The landscape is described in detail, emphasizing the beauty and idyllic character of the region. The beauty of Baumeister's own garden is also present in almost every novel of the series. This impression of the setting as one of beautiful and quiet countryside is supported by the image of the natives. They are fairly stereotypical countrymen who are not accustomed to new technical devel-

1 The Eifel region is situated in the German federal states of North Rhine-Westphalia and Rhineland-Palatinate. In total it encompasses 5,300m2. It ranges from Trier in the south to Aachen in the north, and from the western German border to Koblenz in the east. Beside these important cities, the novels also feature Cologne and Bonn, the former German capital. 
opments, predominantly use their tractors for transport, and consider milking to be their most important daily duty. In the end, a very positive idyllic image is created and the setting cannot be altered easily. Interestingly, the frequent crimes do not convey a threat to the inhabitants; instead they are classified as a welcome change to the familiarity of everyday life (Wigbers 2006, 205-207).

Almost as important as the inhabitants are the figures from outside the Eifel. Firstly, they provide Baumeister with an opportunity to provide more information about the region. Secondly, they illustrate his distinguished position. Baumeister knows the Eifel and, for example, its secret paths very well; but as a former outsider and journalist, he is also familiar with the world beyond and is not as biased as the natives. Following Wigbers (2006, 210), this combination may be regarded as the key factor in the success of the detective as well as the novels.

In sum, the novels convey a detailed description of the region, and people can explore the Eifel guided by Baumeister. But, even after almost thirty years in print, Baumeister remains the insider and always knows a little bit more than the reader. To motivate all this, there is a shift of focus to the locus criminalis. In an attempt to avoid an overly idyllic depiction and a resemblance with so-called Heimatliteratur, crime is brought into play (Wigbers 2006, 208, 212, 216).

As shown in this section, the regional crime novel conforms to Erdmann's observation. Particularly in Germany, its narrative strategies establish a relationship to the Heimatroman. This genre, its history, and its implications for the regional crime novel will be considered in the following section of the article.

\section{Regional crime novels and Heimatliteratur}

An accurate definition of the regional crime novel as a genre has yet to be established. One predominant characteristic identified by a number of scholars is the setting in a broad sense (Frackman 2014, 35). As shown in the previous section, this also applies to Berndorf's Eifelkrimis.

This focus on locality and often idyllic descriptions establishes a connection to so-called Heimatliteratur. This literary genre focuses on a realistic, positive, and emotional depiction of a homeland from the perspective of a native. Both scholarly works and publishers tend to argue that today's regional crime novel establishes and conveys an image of homeland desired by readers (Erdmann 2009, 15-16; Venske 2014, 50).

The idealized world of the setting is of course contrasted with the crime committed in each novel (Kutch and Herzog 2014, 7). This leads to the formation of a new subgenre in German literature that merges the crime novel and the Heima- 
troman (Gerhards 2014, 42-43). As always in literary genres, there is a spectrum from crime as a form of divertissement, as in Berndorf's novels, to the use of the criminal event as a form of social critique. The latter is found, for instance, in the novel Dorfschweigen [Silenced Village] by Jobst Schlennstedt (2012), which discusses racism in German society. It is beyond dispute, however, that the genre overwhelmingly tends towards the former end of the spectrum, and so, in the end, even child abductions do not necessarily lead to a trauma suffered by the victim or their family (Bonter 2015, 99-100).

This primarily positive aspect of the regional crime novel corresponds to its function. As mentioned in the first part of this article, Erdmann links the crime novel in general to the search for cultural identity. Erdmann points out that not only cultural but also individual identity is called into question. Crime fiction now contributes to restoring this lost identity (Erdmann 2009). Precisely this question of identity is defined by Kate M. Quinn as a characteristic function of the regional crime novel, and has been gaining more and more importance in recent years (Frackman 2014, 24).

At this point in time, it has not proved possible to determine the exact relationship between individual identity and region of origin. What we can assume, however, is a tendency for regional background to be a determining factor in individual economic decisions. A study conducted by Caroline Roth-Ebner analysed the Austrian TV programme Starmania. ${ }^{2}$ In her research, Roth-Ebner detected three levels of bonding corresponding to voters' solidarity with candidates: firstly, local affiliations, corresponding to the direct environment of a person; secondly, regional background, in the broader sense of regions or even federal states; thirdly, nationality, which for many viewers constitutes the main reason to prefer the Austrian programme over its German equivalent (Roth-Ebner 2009, 223-226). These results point to a layered preference for the local over the regional over the national, and could be seen as a starting point for the explanation of the ongoing success of regional crime novels.

Beside interest in the reader's own environment, another strong argument for the success of regional crime novels may be the contemporary political situation. This point will be considered in detail in the last section of the article; for now, it should be enough to say that regional crime novels tend to offer reassurance to their readers in hard times and a strong identification with the specific region rather than the whole nation (Venske 2014, 51).

2 This casting show was transmitted in Austria between 2002 and 2009, and is comparable to Pop Idol or The X Factor, with viewers voting via phone calls for their favourite candidates. 
This regional focus was a natural consequence in earlier periods, when mobility was still low. Today, it can be seen as a matter of choice motivated by a crisis of the nation (Claval 1998, 159-160). The place of origin becomes the place where hopes springs eternal (Pott 1986, 13-14). Furthermore, it becomes celebrated in literature and cinema with a particular selection of regional elements (Claval 1998, 159-160). It may well be no surprise to find that the depiction of a setting in regional crime novels is strongly associated with stereotypes and clichés (Erdmann 2009, 22; Frackman 2014, 24). Before we turn to the literary analyses, however, some words regarding the labelling of regional crime fiction are in order.

As mentioned before, the genre of the regional crime novel, unlike, for instance, the mystery novel or thriller, has not been clearly defined. A variety of labels provide orientation (or rather disorientation) for readers. In any German bookstore, one can find Provinzkrimis, Regiokrimis, Inselkrimis, Westfalen-Krimis, Vorgebirgs-Krimis, or sometimes just Kriminalromane "crime novels" - as well as, in the case of serial publications, direct references to the detective protagonist. Although the aim and the concept of the regional crime novel and Heimatliteratur are partially similar, their labelling is not (Gerhards 2014, 45-46). This difference may be due to Germany's Nazi past. During the Nazi regime, the term Heimat was occupied to convey a particular image of Germany, and it was subsequently avoided in post-war Germany (Pott 1986, 8). The Heimatfilm, as a new trend of the 1950s, is nowadays considered kitsch par excellence and yet another reason for publishers and authors to avoid the term (Gerhards 2014, 46-47).

Despite the unsolved question of how to label regional crime novels, the text itself, as well as the accompanying paratexts, will be the focus of the following section.

\section{Heimat in regional crime novels}

We shall consider the use of book covers first. As Erdmann illustrates, general crime fiction tends towards the merging of familiar topoi with something apparently new, or at least with elements of adventure. As examples she refers to the well-known covers of Donna Leon's novels. (Erdmann 2011, 275) On the cover of one of her recent novels (Leon 2017), we can see a solitary gondoliere on the Canal Grande, which makes the locus criminalis quite clear. Meanwhile the touch of yellow, as well as the solitariness of the person on the Canal Grande, also signals a chilly breath of adventure and mystery. In actual fact, except perhaps in January, nobody can be alone on the Canal Grande, not any more. 
Erdmann's observation also applies to the regional crime novel. The use of symbols on their covers gives the reader a clear hint about where the novels are situated as well as associating them with the genre of crime fiction. The cover of Rita Falk's novel Winterkartoffelknödel [Winter Potato Dumpling] (2013) uses the image of a cuckoo clock to place the setting quite clearly in southern Germany. Meanwhile, the use of handcuffs may be seen as a reference to the detective novel, while the names on two cups provide the names of the protagonists. The colour scheme also conveys the image of a humoristic novel. As an interesting aside, the cuckoo clock is traditionally produced in the Black Forest, which is located in another federal state of Germany and some hundred kilometres away from the setting of the novel. This shows that the strategy of the novel's presentation is not attempting to convey an accurate image of Lower Bavaria, but simply to localize the novel in the south of Germany.

The colourful and cosy South stands in opposition to the dark North of KlausPeter-Wolf's Ostfriesenkiller [East-Frisian Killer] (2015) novel. Unsurprisingly, the weather shown in this novel is mainly rainy and cloudy, in contrast to the sunny South. The cover's use of a lighthouse locates the novel quite clearly in northern Germany near the sea. A perceptive customer might also recognize the regionally typical dyke, which others might misinterpret as a hill. The colours convey a more morbid atmosphere compared to the cover of Rita Falk's book, which also corresponds to the content of the novel.

It should become clear that the cover of a novel fulfils a rather crucial function. On the one hand, it provides the reader with an impression of the novel they may be about to buy. On the other hand, it allows publishers to grab attention while still conforming to the well-established stereotypical design for each German region.

A key element of regional crime novels is describing the setting in great detail. Sometimes this may even be done excessively (Frackman 2014, 24). Jacques Berndorf's novel Der letzte Agent begins with the stroll of the protagonist mentioned above. During the walk, he meets a local on the road with his tractor and, in the end, finds the first corpse. His route by car and on foot is described in detail over several pages. An extract should be sufficient here: ${ }^{3}$

Ich schlenderte den Weg entlang; links eine dichte Schonung Weißtannen, rechts ein zehnjähriger Bestand von Mischholz. Nach hundert Metern senkte sich der Weg nach links in eine große Mulde, in der es aussah, als hätten Riesen mit den 25 Meter-Stämmen der Tannen Mikado gespielt. Der Grund war stark verworfen, Erdwälle fielen steil in Gräben ab, unten gluckerte Wasser. Auf einer Fläche von zweihundert mal fünfhundert Meter stand

3 All translations from the German are by Lukas Prebio. 
kein Baum mehr; mein Märchenwald war restlos zerstört, lag in einem chaotischen Durcheinander. (Berndorf 2005)

[I strolled along the path; to the left there was a thick grove of silver firs, while on the right there was a ten-year-old stand of mixed trees. After a hundred metres, the path descended down to the left into a deep hollow, which looked as if giants had played mikado with the 25-metre-tall fir trunks. The ground was completely churned up, earth mounds fell steeply into the trenches, water gurgled down below. In an area of two hundred by five hundred metres there were no trees left; my fairy-tale forest was utterly destroyed, lay in chaotic turmoil.]

This reference in the first-person perspective already shows the strong bonding of the protagonist to the region. He is quite moved by the disappearance of his fairytale wood. The path is described in detail, but is still so vague that nobody would be able to find the place without Jacques Berndorf's Eifel travel guide.

Unsurprisingly, these detailed descriptions may sometimes remind the reader of a travel guide or a road map:

Auf dem Praterstern steht das Denkmal des einzigen österreichischen Seehelden, Wilhelm von Tegethoff, der 1866 bei Lissa die italienische Flotte vernichtend geschlagen hatte. Einst hatte es das Zentrum des Platzes markiert und war ein unübersehbarer Blickpunkt gewesen, heute sagt es kaum einem Menschen mehr etwas, denn Österreich ist ja längst keine Seemacht mehr, sondern besitzt bloß einige kleine Schiffe, die im Volksmund despektierlich als Wienflussmarine bezeichnet werden. (Hinterberger 2007, 46)

[At the Praterstern there is a monument to the only Austrian naval hero, Wilhelm von Tegethoff, who in 1866 thoroughly defeated the Italian fleet near Lissa. Once, it had marked the centre of the square and it had been an unmistakable landmark; today it won't mean a thing to anybody, because Austria has not been a naval power for a long time now, but only owns a handful of small ships, which in common parlance are disparagingly known as the Navy of the Vienna River.]

And:

Er schlug den Weg Richtung Überlinger Innenstadt ein, bog dann am Stadtrand, kurz vor dem Bahnübergang, rechts ab, um über die Sankt-Ulrich-Straße auf die Wiestorstraße zu gelangen, der er ein Stück weit folgte. Nachdem er auf diese Weise die enge Altstadt umfahren hatte, folgte er der beim Franziskanertor stadtauswärts führenden Aufkircher Straße, über die er in wenigen Minuten den weitläufigen Komplex des am nördlichen Stadtrand angesiedelten Überlinger Krankenhauses erreichte. (Megerle 2013, 260-261)

[He headed towards the inner city of Überlingen, turned right at the edge of town, shortly before the railway crossing, to pass via the Sankt-Ulrich-Straße onto the Wiestorstraße, which he followed for a while. After he had circled the old quarter, he followed the Aufkircher Straße leading out of town near the Franziskanertor, until after a few minutes 
he reached the extensive buildings of the Überlingen Hospital near the northern edge of town.]

The main content of the first passage above could conceivably be found in a more substantial travel guide to Vienna. However, the insertion of additional detail on the expression Wienflussmarine makes it more exclusive to the reader. Familiar information like this is directed at an audience which is not content merely to consume more crime fiction but also wishes to gain additional knowledge through the reading process. The regional crime novel provides exclusive facts and privileged insider information about a town or region.

Everybody who has been to Überlingen knows that the description in the second passage is quite unnecessary. Anyone who has been there before knows the way through the city. Meanwhile, those who have not do not gain any more knowledge from the passage. So why this richness of detail? Thanks to modern technologies, interested readers would be able to follow this route quite easily, and it also conveys authenticity to the reader. This directly leads to a common paratext used in regional crime novels: maps.

As Erdmann points out, maps are omnipresent and accessible always and anywhere nowadays via smartphone. Based on their everyday lives, contemporary readers are used to detailed geographical information. Thus the geographical locations of the investigations are also explicitly named. In the past fifty years, a tendency can be observed not only to describe these settings but also to provide the reader with a map. The map, as a classic accessory of travel writing, establishes another connection to the latter literary genre (Erdmann 2011, 274$275,282)$. The use of maps also extends to regional crime novels. An example is the series by Klaus Peter-Wolf. To foster familiarization of the reader with the region of East Friesland, a map of the region can be found directly inside the cover of early volumes. In later volumes, this map has been scrapped in favour of a photograph of the author by the sea. Furthermore, in recent volumes, the chapters are separated by regional symbols like starfish, seashells, or seals (Bonter 2015, 93).

It has been shown that regional crime novels try to convey a very detailed image of the region. Of course, there can be tension between these extensive descriptions and accounts of the investigations in progress. Meanwhile, the sense of regional identity is further strengthened by the use of dialect as well as references to traditional food. Altogether, this often leads to a stereotypical image of a region which is easily accepted by readers. Indeed, readers seem to love these kinds of novels and the regional images created in them. The last section of this article will try to name some of the reasons responsible for this ongoing trend. 


\section{The urge for Heimat}

Heimat is en vogue in the media, while it tends to vanish in postmodern societies (Pott 1986, 8-9). Threatened by globalization and terrorism (Leitner 2009, 165), the urge to preserve one's own origins is constantly on the rise. There are a number of different approaches which may help to explain this phenomenon.

Studies in regional geography show a constant augmentation of mobility in the last fifty years. The introduction of cars, in particular, expanded everybody's economic and social radius. Often, increasing one's mobility is not so much a choice as a necessity required in order to be economically competitive. This tendency has led to a loss of local culture that was the norm for people in the past (Claval 1998, 40, 100-101, 120, 255, 267, 278-279). Nowadays, this loss of culture is often experienced as an absence. People tend to mistrust national structures and try to seek relief in regional traditions. Regional culture is thereby revived in a new way.

The revival of lost traditions, dances, or music is frequently meant to grant participants access to individual regional cultural experiences. Since these experiences often differ from the original meaning of the customs in question, in the long run they contribute to the formation of a pseudoculture. This culture serves the purpose of trying to establish a lost feeling of belonging (Claval 1998, 283).

In Germany, for example, this trend fostered the publication of a variety of magazines like Landlust, LandIdee, LiebesLand, Mein schönes Land, LandGenuss, LandLeben, or Landspiegel. All these magazines convey an image of idealized country life. They portray country life as utterly idyllic. Everybody is happy with their family and has a lot of free time on their hands, which may be dedicated to gardening, cooking, baking, or decorating. This idyllic image may or may not be confronted by reality. In either case, it can be assumed to be one likely explanation for the current interest in regional crime novels.

There are related findings which come from sociology. As a consequence of the Internet as a vehicle of worldwide connection and the ongoing globalization of the world, the term "glocalization" has been coined. Glocalization describes the tendency to use the possibility of gathering information about and from all over the world to view one's immediate surroundings (Koziol 2000, 29).

Similarly, being connected with people all over the world holds a lot of advantages. Thus, virtual acquaintances may always remain more reserved than personal ones since they remain out of immediate proximity and may be perceived as distant. This may ultimately explain the rising significance of the family and other communities, like religious groups, focused on immediate surroundings (Koziol 2000, 38-39). 
This return to reality has also often been related to the attacks of 9/11. On the one hand, these terrorist attacks showed the limits of the so-called McWorld. On the other hand, fundamentalist movements have been using globalization's basis in media culture to further their interests. In the media discourse from 9/11 to the present, Heimat has been established as the opposite concept to international terrorism (Leitner 2009, 165-67).

The key concept of Heimat which is transmitted by the media, including the regional crime novel, is of course a gross oversimplification of reality. However, it provides readers with the individual, regional identities they want to construct for themselves, as well as a peaceful alternative to the ongoing crisis confronting postmodern society.

\section{Conclusion}

This article has shown that the recently developed genre of the regional crime novel is closely tied to developments regarding crime fiction in general. One of the most essential criteria for the regional crime novel can be found in the detailed portrayal of setting. This portrayal not only conveys new knowledge and insights for the reader; it may also be a way of shaping cultural and individual identity. This move towards questions of identity and origins has been fostered by recent developments and threats. Thus, the regional crime novel can be seen as one of many media products to deal with these developments as well as a mechanism for conveying a specific image of Heimat to its readers.

Therefore, it seems necessary to define the genre of the regional crime novel in detail and relate it to other media products concerning the topics of identity, identity construction, and the key concept of Heimat. Secondly, future research should also examine in more detail the reasons for the ongoing boom in these publications, especially where the needs they satisfy as well as their relationship to the current political situation are concerned.

\section{Works cited}

Berndorf, Jacques. Der letzte Agent. Hillesheim: KBV-Verlag, 2005. Kindle edition.

Bonter, Urszula. "Stadt - Land - Mord: Einige Bemerkungen zu den aktuellen deutschen Regionalkrimis." Facetten des Kriminalromans: Ein Genre zwischen Tradition und Innovation. Ed. Eva Parra Membrives. Tübingen: Narr Francke Attempto, 2015. 91-101. Claval, Paul. An Introduction to Regional Geography. Oxford: Blackwell, 1998. 
Erdmann, Eva. "Nationality International: Detective Fiction in the Late Twentieth Century." Investigating Identities: Questions of Identity in Contemporary International Crime Fiction. Ed. Marieke Krajenbrink and Kate M. Quinn, Amsterdam: Brill Rodopi, 2009. 11-26. Erdmann, Eva. "Topographical Fiction: A World Map of International Crime Fiction."

Cartographic Journal: Journal of the British Cartographic Society 48.4 (2011): 274-284.

Falk, Rita. Winterkartoffelknödel: Ein Provinzkrimi. Munich: DTV, 2013.

Frackman, Kyle. "The Functions and Early Roots of German Regional Crime Fiction.” Tatort Germany: The Curious Case of German-Language Crime Fiction. Ed. Lynn M. Kutch and Todd Herzog. Rochester: Camden House, 2014. 23-40.

Gerhards, Sascha. "Krimi Quo Vadis: Literary and Televised Trends in the German Crime Genre." Tatort Germany: The Curious Case of German-Language Crime Fiction. Ed. Lynn M. Kutch and Todd Herzog. Rochester: Camden House, 2014. 41-60.

Hinterberger, Ernst. Mord im Prater: Ein Fall für Trautmann. Vienna: Echomedia-Verlag, 2007. Koziol, Klaus. Die Tyrannei der mediengerechten Lösung: Zur Weltaneignung durch Massenmedien. Munich: KoPäd-Verlag, 2000.

Kutch, Lynn M., and Todd Herzog. “Introduction.” Tatort Germany: The Curious Case of GermanLanguage Crime Fiction. Ed. Kutch and Herzog. Rochester: Camden House, 2014. 1-22.

Leitner, Birgit Maria. "Heimat nach 9/11." Heimat und Fremde: Selbst-, Fremd- und Leitbilder in Film und Fernsehen. Ed. Claudia Böttcher, Judith Kretzschmar, and Markus Schubert. Munich: Meidenbauer, 2009. 165-179.

Leon, Donna. Ewige Jugend: Commissario Brunettis fünfundzwanzigster Fall. Zurich: Diogenes, 2017.

Megerle, Manfred. Seeteufel: Bodensee-Krimi. Cologne: Emons, 2010.

Pott, Hans-Georg. “Der 'neue Heimatroman'? Zum Konzept 'Heimat' in der neueren Literatur.” Literatur und Provinz: Das Konzept 'Heimat' in der neueren Literatur. Ed. Pott. Paderborn: Schöningh, 1986. 7-21.

Roth-Ebner, Caroline. “Das 'Wir-Gefühl' bei der Aneignung crossmedialer Inszenierungen.” Heimat und Fremde: Selbst-, Fremd- und Leitbilder in Film und Fernsehen. Ed. Claudia Böttcher, Judith Kretzschmar, and Markus Schubert. Munich: Meidenbauer, 2009. 215-234. Schlennstedt, Jobst. Dorfschweigen. Cologne: Emons, 2012.

Venske, Regula. "Mystery of Regional Identity: Crime Fiction and Germany's National Identity." Index on Censorship 43.2 (2014): 48-52.

Wigbers, Melanie. Krimi-Orte im Wandel: Gestaltung und Funktionen der Handlungsschauplätze in Kriminalerzählungen von der Romantik bis in die Gegenwart. Würzburg: Königshausen \& Neumann, 2006.

Wolf, Klaus-Peter. Ostfriesenkiller: Kriminalroman. Frankfurt am Main: Fischer, 2015.

Andrea Kreuter is a PhD student in Comparative Literature at the University of Vienna and writing a thesis entitled "The Regional Crime Novel: Outlines of a Popular International Genre.” Her research interests include genre theory, literature and ballet, comparative imagology, literary theories of space, and digital humanities. 